УДК: 331.522

DOI: https://doi.org/10.26661/hst-2020-5-82-14

\author{
(C) ORTINA, GANNA \\ Dmytro Motornyi Tavria state agrotechnological university (Melitopol, \\ Zaporizhzhia obl., Ukraine) \\ E-mail: ortinaganna@gmail.com \\ ORCID iD: https://orcid.org/0000-0001-6244-5759 \\ Таврійський державний агротехнологічний університет імені, пр. Хмельнищького \\ 18, 72312 Мелітополь Україна Запорізька область \\ Dmytro Motornyi Tavria State Agrotechnological University, Hetmanskaya str., 18, \\ 72312 Melitopol, Ukraine Zaporizhzhia region
}

\title{
HUMAN CAPITAL CONCEPT IN THE DIGITALIZATION ENVIRONMENT
}

\begin{abstract}
.
The relevance of the study lies in the fact that the digitalization conditions require the implementation at all managerial levels of the human capital concept, aimed at using all opportunities and their transformation into production processes. The concept was widely spread in the USA, and since the beginning of 60th years all over the world and explosive increase of interest to the human factor theme and the capital invested into it was caused by recognition of its high return in conditions of the Fourth Industrial Revolution. Reality has confirmed the economic growth dependence on the employee, his potential, capacities, features, abilities, education (its different types and levels), professionalism, which turned into a sustainable character. The aim of the article is theoretical and practical foundations for the formation of new knowledge about the human capital concept in the conditions of digitalization. The objectives of the study are: 1) to disclose the process of digitalization as a global problem of our time; 2) to disclose the concept of human capital in the conditions of digitalization and its basic concepts; 3) to show the impact of digitalization on the development of human capital and all its components; 4) to analyze ways and directions to improve the digital skills of human capital. Research methodology: a set of methods, principles, approaches, provide an opportunity to deeply penetrate into the essence and implementation of human capital at all levels of management, that is - synergistic, systematic, structural and functional, promoting its further development in the conditions of digitalization. Research result. Practical recommendations for using the perfection of the concept of human capital and the direction of its use to increase the competitiveness of organizations and enterprises as a condition for the implementation of digitalization.
\end{abstract}

Key words: human capital, digitalization, Fourth production revolution, digitalization skills and abilities

Problem statement in the overall view and its connection with important scientific and practical tasks.

Relevance of the research topic is that digital technology as a global problem, on which the concept of human resource development is based, including the ICT development, technologies based on the possibilities of collection, storage, processing, transmission and data provision in electronic form, requires the new knowledge development.

New technologies, especially artificial intelligence, robotics, 3D printing, are related to significant changes in the labor market, including job cuts in some sectors and the creation of opportunities in others on 
a massive scale. This demonstrates that the concept of human resource development in a digitalized world requires new knowledge, skills, and digital competencies, and requires a collaborative effort between government, civil society, academia, the scientific community and the technology sector. Jim Al-Khalili notes: "Global problems, besides scientific and engineering, also have financial, geopolitical and cultural dimensions, but it is clear that in the coming decades we will need new technologies and knowledge about nature more than ever" [1, p.8].

Analysis of recent studies and publications that have begun to address this problem and on which the author relies.

The human resource development concept aims at mastering those exponential data, increasing every two years, and is the driving force of the digital economy, as data becomes "digital intelligence" and is the basis of human capital. Informatization, automation and digitalization, as defined by J. Neisbit, is a mega-trend in the digital economy development, which is based on cybernetic methods and management tools, large data analysis tools and artificial intelligence. The process of digitization as a global problem of our time, the essence of the human capital concept in the digitalization conditions and its basic concepts we have analyzed in the works of AlKhalili Jim " What next? All that science knows about our future "(2018)

Carlgaard Rich's "Human Factor. The secrets of long-term success of distinguished companies

"(2017)

Navidi Sandra" Superhaba. How the financial elites and their networks manage the world "(2018) Mcston Graham, Randers Jorgen "In search of prosperity. Managing economic development to reduce unemployment, inequality and climate change. Report to the Rome Club "(2017) Macafi Andrew, Brignolfsson Eric "Car, platform, crowd. How to curb our future "(2019) Spence Michael "New convergence. The Future of Economic Growth in a Multilayer World "(2017) In "Riley Tima" Who knows what the future will be "(2018). Digitalization influence on the human capital development and all its components and the analysis of the ways and directions to improve the digital skills of human capital, we analyzed in the works of R. Andriukaytene, V. Voronkovoi, O. Kivlyuk, V. Nikitenko, R. Oleksenko, S. Sosninykh, A. Sosnin. Punchenko's work focuses on the formation and development of a smart society as a highly intelligent, high-tech, high intellectual community, and analyzes such categories as human capital, digitalization, digital skills and abilities, digital intelligence.

The purpose of scientific research is theoretical and practical foundations for the formation of new knowledge about the human capital concept in the conditions of digitalization.

The objectives of the study: 1) to expose the digitalization process as a global problem of our time; 2) to analyze the essence of the human capital concept in the conditions of 
digitization and its basic concepts; 3) show the digitalization impact on human capital development and all its components; 4) to analyze ways and directions to improve human capital digital skills, new knowledge and experience.

Methodology of research: a set of methods, principles, approaches, provide an opportunity to deeply penetrate into the essence and implementation of human capital at all levels of management, that is, synergetic, systemic, structural and functional, promoting its further development in the conditions of digitalization. - comprehension of Ukrainian society as a socio-historical organism is affected by social processes that can strengthen or weaken its integrity and selforganization. Sandra Navidi notes in her "Superhaba" that "if the system does not self-reflect and balance itself, it eventually becomes so curved that it is probable to fail" [3, p. 31].

\section{Discussion of the problem.}

1. The process of digitalization as a global problem of our time.

Digital platforms serve as mechanisms to enable various parties to interact online and promote the development of human capital by collecting new talent and expanding the opportunities of the digital economy and digital government as an activity to create, disseminate and use digital technologies and related information products and services. Today, information, as scientists have proven, is a factor of production, along with labor, land and capital. Digital data, which is underlying the digital economy, is rapidly contributing to the development of data (DIG DATA) such as data analytics, artificial intelligence, blockages, Internet of things, cloud computing and all services provided by the Internet. Business models based on this data are used not only by digital platforms, but also by the world's leading companies in a variety of sectors, and generally opens new and wider opportunities for the digital economy, digital business, digital public management and administration.

The process of digitalization should be considered in a broad and narrow sense. In the wide sense, these are multidimensional organizational and technological processes of mass application of new digital technologies in production and management by reducing costs and increasing the speed of business processes. In the narrow sense, digitalization means the transition from an analog processing form and information transmission and data provision (information) to digital, which is carried out through the use of appropriate technologies and platforms.

According to economic logic, it becomes obvious that digitalization has an impact on accelerating the use of new digital opportunities of market economy as a result of direct digital signals from the external environment; improving the quality of public services by providing administrative and digital services. Turning to the analysis of the term "digitalization", it should be noted that the directions, forms and activities related to the use of ICT, digital 
technologies and large In this context, it is relevant to clarify the conceptual apparatus of digitalization, as assessment of its state and development prospects requires appropriate justification of cloud technologies as a remote access to general computer resources that allow to save and process information and receive a variety of digital services. We have to ask ourselves: what about the impossible can be done with technologies? will they create a society in which you want to live? Because this is the key to transforming the economy and to transforming our daily lives.

If digitalization means a complex, long-term, multidimensional process of converting information and management technologies and information resources into a state beneficial and necessary for the effective application of digital implementations and technologies, it means increasing the reliability of collection, systematization, transmission and storage (through discrete sensors of Internet things, Reid-labels, cost reduction and simplification of communications in the economy and society (digitalization of content and communication facilities), creating a model for multi-interaction of people and business processes, creation of a model for multi-interaction of people and business processes in the context of vertical and horizontal (between organizational digital systems). RFID technology as a technology for automatic identification of objects allows through radio signals to read and record data stored in RFID tags, which indicates the strengthening, further development of digital society as a high-tech, dominated by breakthrough, cognitive technologies.

1. The human capital concept under digitalization conditions.

The human capital concept in the conditions of digitization includes the analysis of various ratings and indices of countries and the need to develop this concept in accordance with human (social, intellectual, structural, cognitive) capital, including:

1) ICT Development Index (IDI)

2) Digital Economy and Society Index (DESI)

3) IMD World Digital Competitiveness Index (WDCI)

4) Digital Evolution Index (DEI)

5) Economic Digitalization Index (Boston Consulting Group - eIntensity)

6) Networked Readiness Index (NRI)

7) The UN Global E-Government Development Index (EGDI)

8) Electronic Participation Index (E-Participation Index - EPART)

9) Electronic connectivity index (Global Connectivity Index - GCI, Huawei)

10) The Global Innovation Index (GII).

The methodology of countries rating formation on human capital concept implementation development is created in the form of three-level hieracic structure:

1) readiness of the country for implementation of new digital technologies and use of human potential;

2) intensity of application of digital technologies in all spheres of 
economy, production, management with use of human capital;

3) influence of digital technologies on development of human capital and talents, as development of digital economy better promotes development of talents. Chris Skinner in "The Digital Man" notes that billions of people who previously had no access to digital services are now online "[4, p. 21].

At the basis of the human resources concept in digitalization is the development of human talents and their capabilities. There is a correlation between profit, availability of talents and competitiveness of countries, which is based on the causal link between the effectiveness of talent functioning and economic growth, job creation and innovation. Entrepreneurial talent helps reduce inequality and the success of small firms and start-ups that are crucial for innovation. "Revolutionary inventions (sensors, computer and control technology) in the 21st century are turning the 20th century view of everyday activities around. This is the potential of technology to expand human capabilities [7, p.18].

All components of the innovative concept of digitalization should intensify efforts to attract and retain a large number of entrepreneurial talents that represent the symbiosis of human mind and technology, economy and nation. Digitalization increases the importance and role of entrepreneurial talent, the rapid spread of artificial intelligence radically affects the future of the labor market, the share of hired workers continues to decline, while new business models, especially on digital platforms, are emerging.

The concept of human development in the conditions of digitalization is one of the basic directions of knowledge management and comes out to accumulate human capital in terms of developing relevant skills and abilities. Graham Macston and Jorgen Randers in "In Search of Well-being. Managing economic development to reduce unemployment, inequality and climate change. The report to the Club of Rome "notes that" the Wave of computerization and robotization offers a rapid breakthrough in production and robotic enterprises, it has led to a radical reduction in the number of people who work in such companies, bagatomonotonnyh works will disappear, and there will remain only those that require direct human participation "[4, p. 94-95].

1. Influence of digitalization on development of human capital and all its components. Main directions of human potential development.

The purpose of the concept of human capital is to define a set of skills necessary for workers in the digital economy. The basis of human capital development in the working space of an enterprise experiencing global changes should be called the triad: 1) Digital skills (digital skills); 2) Soft skills (flexible skills); 3) Skills of information analysis and processing. To use within these limits only purely digital skills of human capital seems insufficient and will not meet the requirements of the new way of the digital era, producing mechanisms for effective teams, 
because people are the most valuable capital of any organization. "People are still livelier and more agile for modern robots. This is likely to be the case in the near future. These abilities, combined with our feelings and problem solving skills, guarantee us a job side by side with the work," said Macafi Andrew, Brignolphsson Eric. Machine, platform, crowd. How to curb our future [5, p.105].

The basic digital skills of human capital (Digital Competence Framework) applied in the European Union include information acquisition, online communication, digital content creation, electronic security, text and computer editors, ability to fill out forms, ability to edit media files and documents, work with e-commerce in all roles, the ability to customize the program to their requirements, engage in basic programming and adjust the digital management skills (The Digital Competence, 2017), which requires the development of a program "digital minimum" and the legendary goal.

Mastering human capital skills Soft skills (Gucko Technology), by definition, includes up to 10 positions, including teamwork and communication skills, flexibility, communication skills, leadership, critical and systemic thinking, responsibility, work ethics (Executive Perceptions 2013).

Human capital skills - analysis and processing of information (Digital Competence Framework) have include effective memorization, information retrieval, text analysis, overcoming fragmented thinking, forming a holistic picture of the world. It is on the basis of these skills of digital, flexible and information processing that the concept of human capital is formed and is in demand in the digital society of the European community. The basis of employment is "work in the cloud", which includes, by analogy with the term "Cloud Computing", all kinds of remote employment, 574 atypical forms of employment, carried out through the mediation of ICT, which are determined by changes caused by the technological revolution, based on which the speed of technology and the intangible component of business as the basis for long-term success. "Whereas previously computers worked for people, now the opposite is true - mainly people work on computers. In today's world, change managers are algorithms," says $\mathrm{O}$ 'Riley Tim in Work' Who knows what the future will be like, "so we need to form algorithmic thinking and algorithmic culture [7, p. 20].

Experts predict that about $47 \%$ of jobs will be "digitized" in the near future, and computer programs will replace the employee. There is also a viewpoint that digitalization, robotization and use of artificial intelligence will form new jobs and will not displace workers on the labor market, will increase the demand for human labor by redistribution and creation of new jobs ready to serve and control the work of new digital technologies.

The impact of digitalization on the development of human capital in that it occurs in the reduction of the number of jobs, in changing the professional and qualification 
structure of the employed population, in the emergence of new forms of employment, in changing professional requirements to human potential, in changing the motivation of staff to work. As Tom Kelly and David Kelly note in their work, "Creative confidence. What to unlock your potential," today we see the challenge of helping as many people as possible to find their creative potential, to discover it, to find their new opportunities "[3, p.22].

According to the concept of human potential, digital technologies influence external factors (new technologies, legislation, rules of organization) and internal factors (employee potential, abilities, professionalism, skills), which generally affects the competitiveness of the firm or organization. In conditions of digital transformation the competitiveness of human potential depends on modern digital skills of the 21st century, which are understood as the ability to localize, organize, understand, develop, create and disseminate information, using the competences at different levels of management.

There are many different interpretations relating to the ability to use information and communication technologies, as digital literacy, digital competence, computer literacy, e-skills, as the human component is the only competitive advantage in the digital economy, e-business. "It is practically impossible to overestimate the long-term importance of information technology development and its integration into the world economy. Many people consider them to be one of the most important elements of their involvement in the connected global economy, "their use in market processes and supply chains that connect the global economy," says Spence Michael in his paper, "New convergence. The future of economic growth in a multilayered world [6, p. 276]. Access to valuable human resources (regardless of where they are located and their productivity) is a valuable resource for the network economy, and innovation is the main source of productivity growth. The development of big data technologies illustrates three decisive stages: 1 ) create new knowledge; 2) share it; and 3) implement tools that will be used by less skilled workers. New problems create new solutions - fruits of human labor and contribute to the development of talents.

4. Identification of ways and directions to improve digital skills of human capital

In connection with these trends it is necessary to identify ways and directions to improve the digital skills of human capital: 1) development and implementation of government programs (European Union - Digital Skills and Jobs Coalition; 2) outsourcing training of employees to companies that specialize in the development of digital skills (ISDI, Digital Marketing Institute); 3) intracompany training of employees by organizations and development of corporate universities (Pixar, Google and others); 4) self-study (distance courses like Coursera and others); 5) systematization of domestic and foreign experience in improving 
digital skills, which are the basis for indicators - economic, socio-political, socio-psychological and others to improve the competitiveness of modern companies by improving the digital skills of human capital, through which people get more opportunities for career advancement. Carlgaard Case in "The human factor. The secrets of long-term success of outstanding companies offer and defend a balanced triangle of forces: 1) "material advantages" - those systems and processes that guide the complex tasks of managers to develop human resources; 2) "strategic framework" - the organization will not develop if it has no strategic direction in human resource development; 3) non-material advantages, which are the guarantee of human values and sustainability and are the basis of human capital development and its embodiment in the digital economy [2, p.20].

Automation and low-cost production contributed to a significant increase in demand for new goods and services. Now again, the time has come when people should be provided with new jobs and new types of prosperity. Historical waves of technological digital progress have taught mankind to think the unthinkable and realize the impossible. A digital society needs new digital mechanisms through which professionals can learn and acquire new skills throughout their lives, a need that workers in various industries now have. The opportunity to learn and access educational resources attracts a skilled workforce. The concept of "work" is changing, the need for education is not disappearing, but is even growing. In a world interconnected by the Internet, where knowledge is available on demand, it is time to rethink what people need to know and how to gain knowledge. Now begins the transition from people developed models of machine learning to tools that allow developers to produce such models regularly. When it happens, artificial intelligence will irrevocably change the world, just as mass production in the XIX and XX centuries has changed industrial management. By combining efforts with the latest technologies, organizations are able to work wonders.

\section{Conclusions.}

1. Analyzing the foreign experience of digitalization, we note that developed countries such as Japan, the United States, Great Britain, Germany, and France have realized that the necessary condition for digitalization is the development and maximum disclosure of workers' creative potential, that is why they pay special attention to this and receive appropriate results " human component of " economy. These countries attract " the best and brightest" from all over the world as objects of innovation and economic activity, understanding the importance of human capital and finding the necessary motivators for their work, but still companies do not manage to take up new opportunities and think ahead. To develop a viable strategy, companies have to take into account their own resources and forecasting horizons and take advantage of the huge potential to transform a society 
where training, creativity and human efforts will be more valued than today.

2. Human potential is the most important strategic factor that determines both the success of reforms and the prospects for resuming economic growth in Ukraine, based on algorithms, information, knowledge and innovations, the use of information and computer technologies, pushes that the search for unused resources, optimal ways for effective long-term development of the country should be carried out in the plane of understanding the human development concept, is developing in network platforms, and represents a powerful tool to shape the next generation economy. The ability of companies to use new technologies largely depends on the ability of management to train staff and change workflows, companies have responded to flexible, multidisciplinary approaches based on data and consumer-oriented, is now practiced in Silicon Valley countries.

\section{СПИСОК ВИКОРИСТАНИХ ДЖЕРЕЛ}

1. Аль-Халілі Джим (2018). Що далі? Все, що наука знає про наше майбутнє / пер. 3 англ. М. Климчука. Київ : Кі Фонд Медіа. 248.

2. Карлгаард Річ (2017). Людський фактор. Секрети тривалого успіху видатних компаній / пер. з англ.. Олени Любенко. Київ : Книголав. 336.

3. Навіді Сандра (2018). Суперхаби. Як фінансові еліти та їхні мережі керують світом / пер. 3 англ. Лесі Стаханів і Сергія Грицаєнка. Київ : Yakaboo Publishing. 368.

4. Макстон Грем, Рандерс Йорген (2017). У пошуках добробуту. Керування економічним розвитком для зменшення безробіття, нерівності та змін клімату. Доповідь Римському клубу / пер. $з$ англ. Катерина Гуменюк та Яна Сотник. Київ : Пабулум. 320.

5. Макафі Ендрю, Бріньолфссон Ерік (2019). Машина, платформа, натовп. Як приборкати наше майбутне / пер. з англ. Олександра Асташова. Київ. : Наш формат. 336.

6. Спенс Майкл (2017). Нова конвергенція. Майбутнє економічного зростання в багатошаровому світі. Київ : Темпора. 352.

7. O’ Райлі Тім (2018). Хто знає, яким буде майбутнє / пер. 3 англ. Юлія Кузьменко. К. : Наш формат. 448 с.

8. Андрюкайтене, Р.,Воронкова, В., Кивлюк, О., Никитенко, В. (2017). Становление и развитие smart-общества как высокоразумного, высокотехнологического, высокоинтеллектуального. Гуманітарний вісник Запорізької державної інженерної академії. 71. 17-25.

9. Нікітенко В.О. (2013). Геокультурні цінності в умовах сучасного світового розвитку: соціально-філософський вимір. Вип. 54. 266-280. Гуманітарний вісник Запорізької державної інженерної академії.

10. Олексенко Р. I. (2015). Філософія розвитку інформаційного суспільства в епоху глобалізації. Гілея: науковий вісник. Вип. 98. 230-232

11. Олексенко Р. (2015). Епоха глобалізації, їі вплив на інформаційне суспільство. П'ята всеукраїнська наукова конференція «Сучасні соціально-гуманітарні дискурси». 56-59.

12. Соснін О. В., Воронкова В. Г., Ажажа М. А. (2016). Філософія гуманістичного менеджменту (соціально-політичні, соціально-економічні, соціально-антропологічні виміри): навчальний посібник. Запоріжжя: Дике поле.356.

\section{REFERENCES}

1. Al`-Xalili Dzhy`m (2018). Shho dali? Vse, shho nauka znaye pro nashe majbutnye / per. z angl. M. Kly`mchuka. Ky`yiv : Ki Fond Media. 248.

2. Karlgaard Rich (2017). Lyuds`ky`j faktor. Sekrety` try`valogo uspixu vy`datny`x kompanij / per. z angl.. Oleny` Lyubenko. Ky`yiv: Kny golav. 336. 
3. Navidi Sandra (201ë8). Superxaby`. Yak finansovi elity` ta yixni merezhi keruyut`svitom / per. z angl. Lesi Staxaniv i Sergiya Gry`czayenka. Ky`yiv : Yakaboo Publishing. 368.

4. Makston Grem, Randers Jorgen (2017). U poshukax dobrobutu. Keruvannya ekonomichny`m rozvy`tkom dlya zmenshennya bezrobittya, nerivnosti ta zmin klimatu. Dopovid`Ry`ms`komu klubu / per. z angl. Katery`na Gumenyuk ta Yana Sotny`k. Ky`yiv : Pabulum. 320.

5. Makafi Endryu, Brin`olfsson Erik (2019). Mashy`na, platforma, natovp. Yak pry`borkaty` nashe majbutnye / per. z angl. Oleksandra Astashova. Ky`yiv. : Nash format. 336.

6. Spens Majkl (2017). Nova konvergenciya. Majbutnye ekonomichnogo zrostannya v bagatosharovomu sviti. Ky`yiv : Tempora. 352.

7. O' Rajli Tim (2018). Xto znaye, yaky`m bude majbutnye / per. z angl. Yuliya Kuz`menko. K. : Nash format. 448.

8. Andriukaitene, R., Voronkova V., Kivliuk, O., Nikitenko, V. (2017). Stanovlenie i razvitie smart-obshchestva kak vysokorazumnogo, vysokotekhnologicheskogo, vysokointellektualnogo. Gumanitarny `j visny`k Zaporiz koyi derzhavnoyi inzhenernoyi akademiyi. Vip.71. 17-25.

9. Nikitenko V.O. (2013). Geokul turni cinnosti v umovax suchasnogo svitovogo rozvy`tku: social`no-filosofs`ky`j vy`mir. Gumanitarny`j visny`k Zaporiz`koyi derzhavnoyi inzhenernoyi akademiyi. Vy`p. 54. 266-280.

10. Oleksenko R. I. (2015). Filosofiya rozvy`tku informacijnogo suspil`stva v epoxu globalizaciyi. Gileya: naukovy`j visny`k. Vy`p. 98. 230-232

11. Oleksenko R. (2015). Epoxa globalizaciyi, yiyi vply`v na informacijne suspil`stvo / R. Oleksenko. P'yata vseukrayins`ka naukova konferenciya «Suchasni social `no-gumanitarni dy`skursy`». 56-59.

12. Sosnin O. V., Voronkova V. G., Azhazha M. A. (2016). Filosofiya gumanisty`chnogo menedzhmentu (social`no-polity`chni, social`no-ekonomichni, social`no-antropologichni vy`miry`): navchal`ny`j posibny`k. Zaporizhzhya: Dy`ke pole. 356.

ОРТІНА, Г. В. - доктор наук державного управління, доцент, доцент кафедри публічного управління, адміністрування і права Таврійського державного агротехнологічного університету ім. Дмитра Моторного (Мелітополь, Україна)

E-mail ortinaganna@gmail.com

ORCID iDhttps://orcid.org/0000-0001-6244-5759

\section{КОНЦЕПЦІЯ ЛЮДСЬКОГО КАПІТАЛУ В УМОВАХ ЦИФРОВІЗАЦЇ̈}

Анотація. Актуальність дослідження у тому, що умови цифровізації вимагають упровадження на всіх рівнях управління концепції людського капіталу, націленої на використання всі можливостей і їх трансформацію у виробничі процеси. Концепція набула широкого розповсюдження в США, а з початку 60-х років XX ст. по всьому світі і вибухове підвищення інтересу до теми людського чинника та вкладеного у нього капіталу було обумовлене визнанням високої його віддачі в умовах Четвертої промислової революції. Дійсність підтвердила факт залежності економічного росту від працівника, його потенціалу, можливостей, особливостей, здібностей, освіти (різних iї видів і рівнів), професіоналізму, що перетворилося на стійкий характер. Мета статті - теоретичні та практичні засади формування нових знань про концепцію людського капіталу в умовах цифровізації. Завдання дослідження: 1) розкрити процес цифровізцаії як глобальну проблему сучасності; 2) розкрити суть концепції людського капіталу в умовах цифровізації та основні іiі концепти; 3) показати вплив цифровізації на розвиток людського капіталу та всіх його складових; 4) здійснити аналіз шляхів та напрямів покращення цифрових навичок людського капіталу. Методологія дослідження: сукупність методів, принципів, підходів, що дають можливість глибоко проникнути у сутність та упровадження людського капіталу на всіх рівнях управління, а саме, - синергетична, системна, структурно-функціональна, що сприяють іiі подальшому розвитку в умовах цифровізації. Результат дослідження. Практичні рекомендації використання удосконалення концепції людського капіталу та напрями його використання для підвищення конкурентоспроможності організацій, підприємств як умови упровадження цифровізації.

Ключові слова: людський капітал, цифровізація, Четверта промислова революція, цифрові навички і вміння 
ОРТИНА, А. В. - доктор наук государственного управления, доцент, доцент кафедры публичного управления, администрирования и права Таврийского государственного агротехнологического университета им. Дмитрия Моторного (Мелитополь, Украина)

E-mail ortinaganna@gmail.com

ORCID iD https://orcid.org/0000-0001-6244-5759

\section{КОНЦЕПЦИЯ ЧЕЛОВЕЧЕСКОГО КАПИТАЛА В УСЛОВИЯХ ЦИФРОВИЗАЦИИ}

\section{Аннотация.}

Актуальность исследования в том, что условия цифровизации требуют внедрения на всех уровнях управления концепции человеческого капитала, нацеленной на использование всех возможностей и их трансформацию в производственные процессы. Концепция приобрела широкое распространение в США, а с начала 60-х гг. XX века по всему миру и взрывное повышение интереса к теме человеческого фактора и вложенного в него капитала было обусловлено признанием высокой его отдачи в условиях Четвертой промышленной революции. Действительность подтвердила факт зависимости экономического роста от работника, его потенциала, возможностей, особенностей, способностей, образования (разных его видов и уровней), профессионализма, который превращается в устойчивое развитие. Цель статьи теоретические и практические основы формирования новых знаний в концепцию человеческого капитала в условиях цифровизации. Задачи исследования: 1) раскрыть процесс цифровизации как глобальную проблему современности; 2) раскрыть сущность концепции человеческого капитала в условиях цифровизации и основные ее концепты; 3) показать влияние цифровизации на развитие человеческого капитала и всех его составляющих; 4) осуществить анализ путей и направлений улучшения цифровых способностей человеческого капитала. Методология исследования: совокупность методов, принципов, подходов, которые предоставляют возможность глибоко проникнуть в сущность и внедрение концецпии человеческого капитала на всех уровнях управления, а именно, - синергетическая, системная, структурно-функциональная, которые содействуют ее дальнейшему внедрению в условиях цифровизации. Результат исследования. Практические рекомендации усовершенствования концепции человеческого капитала и направления ее использования для повышения конкурентоспособности организаций, предприятий как условия внедрения цифровизации.

Ключевые слова: человеческий капитал, цифровизация, Четвертая промышленная революция, цифровые умения и привычки

Received date 01.11.2020

Accepted date 10.11.2020

Published date 15.11.2020 